\title{
Brazilian private health system: history, scenarios, and trends
}

\author{
June Alisson Westarb Cruz ${ }^{1,2,3^{*}}$, Maria Alexandra Viegas Cortez da Cunha' ${ }^{1}$, Thyago Proença de Moraes², \\ Sandro Marques ${ }^{2,4,5}$, Felipe Francisco Tuon ${ }^{2}$, Arivelton Loeschke Gomide ${ }^{3}$ and Gisele de Paula Linhares ${ }^{3}$
}

\begin{abstract}
Background: Health care is a complex economic and social system, which combines market elements and public and social interest. This combination in Brazil, like systems in China and United States of America, is operationalized through the public and private system. The sector represents approximately $9 \%$ of the country's GDP, of which $56 \%$ is privately sourced and $44 \%$ is of public origin. In the private sector includes a structure with 711 private health institutions, 47 million beneficiaries and revenues of US\$30 billion a year.

Methods: Therefore, this research describes and analyzes the complementarity of Private Health before the Brazilian Unified Health System, highlighting its main characteristics, scenarios, and trends in the face of the health system and the Brazilian market. This descriptive and exploratory research uses secondary data from various sources, submitted to quantitative data analysis methods. The object of the research is the history of private health in Brazil and its main actors.
\end{abstract}

Results: The data are organized into three groups, each with its approach of collection and analysis. Thus, it is perceived as the notorious growth of large operators, to the detriment of operators with a lower concentration of beneficiaries; the increasing concentration of the market through mergers and acquisitions promoted by large publicly traded corporations, especially in regions with a lower rate of private health coverage; and the growth of the sector through business plans, whose central characteristic is the dependence on the country's employability rate.

Conclusions: It is possible to perceive an intense trend of concentration of Brazilian private health in large institutions that have capitalized and have a great appetite for growth through mergers and acquisitions, whether from smaller operators or health institutions that integrate their health networks, following complementary health models already consolidated in countries such as China, and the United States of America, among others. This concentration projects a market with fewer options and competitiveness, reduction in transaction costs and increase the operational effectiveness of health care.

Keywords: Private health, Brazil, Market concentration

\section{Introduction}

Brazil is a country of continental dimensions, with a territory of 8.5 million square kilometers and a population of 211 million people, being the sixth most populous

\footnotetext{
*Correspondence: june.cruz@pucpr.br

${ }^{3}$ School of Business, Pontifical Catholic University of Paraná, Curitiba,

Paraná 80215-901, Brazil

Full list of author information is available at the end of the article
}

country on earth [1]. Its health system comprises the state's performance through the Unified Health System, and the private initiative [2].

Since the 1990s, many efforts have been devoted to health care in Brazil by public or private means. Although the efforts are commendable, the country presents many challenges around health [3] owing to the intense socioeconomic inequality present in the country [3-5]. This 
can be verified by the degree of income concentration, also known as a measure of inequality, the Gini index of 50.9 [1, 4], a value measurement of countries such as Zambia (57.1) [6] and Zimbabwe (50.3) [6].

Like the challenges of the Canadian [7] and United States of America systems [8], the Brazilian health system is formed by a complex and challenging network of health service providers and buyers [9], all with intense challenges of promoting an adequate cost-effectiveness ratio in health $[10,11]$.

With the public and private actors, the Brazilian health system is divided into two sectors: public and private. The public sector comprises state funding; the private sector is financed by public and private resources, mostly for profit, and comprises different modalities of insurance and private health plans [12]. Table 1 describes the main characteristics of each of the members of the health sector in Brazil.

Historically, private health systems have been stimulated by a series of government policies, either through the accreditation of services, and the remuneration and creation of hospital units among others [13].

The health sector in Brazil represents approximately $9 \%$ of the GDP [4, 14], of which $56 \%$ has a private and $44 \%$ has a public origin $[4,15]$. The health sector employs 4,418,871 [14] people and comprises a structure with 711 private health institutions [16], 256 dental plan operators [16] and 6642 hospital units [17] among others.

The Unified Health System, created from the Federal Constitution of 1988 [4], is based on the principle of health as a citizen's right and duty of the state1. Currently, approximately $75.5 \%$ of the Brazilian population is served solely and exclusively by the Public System [18], which, despite its historical achievement in scope and access, suffers strongly owing to chronic underfunding $[4,5]$.

The other $24.5 \%$ of the population have access to health through private health [16], which is strongly linked to

Table 1 Overview of the health system in Brazil

\begin{tabular}{|c|c|c|}
\hline Description & Public & Private \\
\hline System & Unified Health System & Private Health \\
\hline Main Regulatory Body & Ministry of Health & $\begin{array}{l}\text { National } \\
\text { Agency for } \\
\text { Supplementary } \\
\text { Health }\end{array}$ \\
\hline Funder & $\begin{array}{l}\text { Union, States and Municipali- } \\
\text { ties }\end{array}$ & $\begin{array}{l}\text { Individuals and } \\
\text { Legal Entities of } \\
\text { a Private Nature }\end{array}$ \\
\hline Service Provider & Public and Private Entities & Private Entities \\
\hline Year Regulation & 1988 & 1998 \\
\hline Coverage & Universal & Consumers \\
\hline
\end{tabular}

the care of people through individual or family contracts (19\%), business (68\%) and collective (13\%) [16].

Private performance in Brazilian health has intensified since 1964, after the military coup, when a series of reforms drove the expansion of the private health system. Since then, a series of historical events have fostered private performance in the health sector, leading to a significant expansion of the provision of health services through private health [12], as described in Table 2 below:

Currently, private health is regulated and supervised by several government and organized civil society institutions and forums such as the Supplementary Health Council [26], National Supplementary Health Agency [16] and Supplementary Health Chamber [27]. Its operation takes place through private health institutions, which are assigned to manage, market, and provide health plans, with the purpose of medical, hospital and dental care to their beneficiaries [26].

As of December 2020, there were 47,631,224 private health users [16], assisted by 711 hospital medical operators [16], with revenues of 30.4 billion (US\$). Table 3, some of the main data of the sector and its respective representation in the Brazilian context.

In view of the initial presentation of the sector and the notorious importance of Private Health in the Brazilian context, the objectives, methods, results, discussions, and conclusions of the research are presented below.

\section{Objectives}

The main objective of this study is to understand the general and specific context of Brazilian private health, its scenarios, and trends, with emphasis on the analysis of market concentration and recent processes of mergers and acquisitions.

\section{Methods}

\section{Study design and technical aspects of research}

This research is described as descriptive and exploratory, with the use of secondary data from various sources submitted to quantitative data analysis methods. The object of the research is the history of private health in Brazil, as well as its main actors. The data are organized into three groups, each with its approach to collection and analysis, as shown in Table 4 below:

The first group of "Historical and Regulatory Documents" plays an important role in the research, as it allows the identification and analysis of the relevance and history of the private health sector in the Brazilian context.

The second group called "Sector Data" presents a descriptive statistical analysis and explains the historical series of evolution of the sector, as well as the 
Table 2 Historical series of relevant private health events in Brazil

\begin{tabular}{|c|c|}
\hline Period & Event Description \\
\hline $1500-1822$ & Creation of hospital structures - Santas Casas [19] \\
\hline 1897 & Creation of the General Directorate of Public Health [20] \\
\hline 1889-1930 & Start of health care and social security system [20] \\
\hline 1933-1938 & Extension of social security to most workers in urban areas [21] \\
\hline 1953 & Creation of Ministry of Health [12] \\
\hline 1950-1960 & $\begin{array}{l}\text { Beginning of the first medical entities providing services financed by companies, with } \\
\text { service predominantly focused on industrial workers [22] }\end{array}$ \\
\hline 1964 & Initial development of private health companies (Decree-Law 200) [22] \\
\hline 1964 & Expansion of hospital structures [12] \\
\hline 1964-1988 & $\begin{array}{l}\text { Crisis in the health system and social security } \\
\text { Expansion of the health system by private means }[12,23]\end{array}$ \\
\hline 1988 & Decentralization of the Health System [24] \\
\hline 1990 & Creation of the Unified Health System (Law 8080 and 8142) [4] \\
\hline 1996 & Creation of the Provisional Contribution on Financial Transactions [24] \\
\hline 1998 & Regulation of private health plans [24] \\
\hline 1999 & Creation of the National Health Surveillance Agency [24] \\
\hline 1999 & Beginning of private equity practice in private health companies [25] \\
\hline 2000 & Creation of the National Agency for Supplementary Health (Law 9961) [24] \\
\hline 2000 & Definition of health financing responsibilities - Constitutional Amendment 29 [24] \\
\hline 2001 & Psychiatric Reform Law [24] \\
\hline 2004 & Start of capital opening of Brazilian health companies [25] \\
\hline 2006 & Pact for Health [24] \\
\hline 2006 & Creation of the National Primary Care Policy and the National Health Promotion Policy [24] \\
\hline 2008 & Creation of 24-h Emergency Care Units [24] \\
\hline 2011 & Creation of Private Plan Operators Program - ANS Resolution 277 [16] \\
\hline 2019 & Minimum Governance Practices - ANS Resolution 443 [16] \\
\hline
\end{tabular}

measurement of the indices of market concentration $\mathrm{IHH}$ - Herfindahl-Hirschman (1) and RC5 - Concentration Ratio of the five largest [29] role players, adapted to the private health sector, according to equations below: version 7.724. From the elaboration of the adjacency matrix, the analysis of the patterns of interactions of processes of division, incorporation, and mergers between entities of health legal entities was elaborated, with graph theory analysis based on the identification

$$
\mathrm{IHH}=\sum \mathrm{ni}=1 \text { (Carrier Beneficiaries Amount/Total Private Health Beneficiaries) }
$$

$$
\mathrm{RC} 5=\sum 5 \mathrm{i}=1 \text { (Beneficiary Amount of the Five Largest Volume/Total Private Health Beneficiaries) }
$$

The resulting analysis of the $\mathrm{IHH}$ and RC5 assume values between 0 (no market concentration) and 1 (total market concentration). For analysis and interpretation, the scale of the credit market analysis was adapted, where estimates between 0.10 and 0.18 represent moderate concentration and, above 0.18 , high market concentration.

The third group, "market", presents an analysis of relational networks through the Software Ucinet [30], of private health institutions that appear as buyers or sellers, in the period from 2018 to 2020. This analysis methodology uses graphs to be analyzed descriptively and square or rectangular matrices, also known as socio matrices $(X)$. The matrices allow the visualization of relationships and patterns that would hardly be perceived in the sociograms of points and lines. In the matrices, the rows ( $g$ ) represent the sent links, 
Table 3 General data on the representativeness of Private Health in Brazil

\begin{tabular}{|c|c|c|}
\hline Description & 2010 & 2020 \\
\hline Health Spending (\% of GDP) $[4,14]$ & 8.3 & 9 \\
\hline Proportion spent on Private Health $(\%)[4,15]$ & 54.2 & 56.07 \\
\hline Proportion spent on Public Health (\%) $[4,15]$ & 45.8 & 43.93 \\
\hline Coverage Rate on Private Health Plans (\%) [16] & 22.3 & 24.5 \\
\hline The Hospital Medical Organization (Unit) [16] & 1045 & 711 \\
\hline The Dental Organization (Unit) [16] & 374 & 256 \\
\hline Assets of Private Health Entities (US\$ - Billions) [26] & $\$ 11,764.71$ & $\$ 21,323.53^{b}$ \\
\hline Private Health Programs (Users) [16] & $44,937,350^{\mathrm{a}}$ & $47,615,162$ \\
\hline U-files of individual or family plans (Users) [16] & $9,560,381^{a}$ & $9,043,414$ \\
\hline Users of Business Plans (Users) [16] & $28,877,931^{\mathrm{a}}$ & $32,192,328$ \\
\hline U-kind Collective Plans (Users) [16] & $6,643,512^{a}$ & $6,308,420$ \\
\hline Users of Unidentified Plans (Users) [16] & $943,990^{\mathrm{a}}$ & 71,000 \\
\hline And Direct Jobs in Health (People) [14] & - & $4,418,871$ \\
\hline And Direct Jobs in the Private Health Sector (People) [14] & - & $3,429,759$ \\
\hline And Direct Jobs in the Public Health Sector (People) [14] & - & 989,112 \\
\hline Revenue from Private Operators Payouts (US\$) [16] & $\$ 15,592,201,463.79$ & $\$ 30,498,100,687.32$ \\
\hline Operator Assistance Expenses (US\$) [16] & $\$ 12,658,972,366.36$ & $\$ 22,090,892,703.13$ \\
\hline Operator Administrative Expenses (US\$) [16] & $\$ 2,427,299,367.83$ & $\$ 2,886,992,082.35$ \\
\hline Operators'Business Expenses (US\$) [16] & $\$ 504,765,502.02$ & $\$ 961,252,886.21$ \\
\hline Hospital Structures (Units) [17] & 6907 & 6642 \\
\hline Hospital Beds Brazil (Unit) [17] & 435,793 & 404,770 \\
\hline Private Hospital Beds (Unit) [17] & 295,463 & 254,982 \\
\hline Beds per Thousand Inhabitants (Thousand Inhabitants) $[17,28]$ & 2.23 & 1.91 \\
\hline
\end{tabular}

2011

b 2016

Table 4 General framework of research methods

\begin{tabular}{llll}
\hline Group & Source data & Data Type & Form of Analysis \\
\hline $\begin{array}{l}\text { Historical and regulatory } \\
\text { documents }\end{array}$ & Sites and reference searches & Documents and laws & Descriptive documentary analysis \\
$\begin{array}{l}\text { Industry Data } \\
\text { Market }\end{array}$ & Industry data repository sites & quantitative & Quantitative data analysis \\
\hline
\end{tabular}

while the columns (h) represent the received links or (j). The links sent and received have important implications for the calculation of local and global centrality degrees and in the identification of subgroups in the network. The notation for representation of a socio matrix can be expressed in (3).

$$
\mathrm{X}-\mathrm{gxh}
$$

The data sources for identifying the operations of mergers and acquisitions, from data mining on sites specializing in them totaling 196 sources can be consulted through Additional file 1.

\section{Results}

The private health operate through more than one corporate typology of a legal entity, called "modalities" [16]: group medicine (40\%), medical cooperatives (36\%), health insurers (13\%), self-management (9\%) and philanthropy (2\%). These organizations establish contracts for the provision of health services with their beneficiaries, protecting their users from the direct cost linked to the risk of falling ill and observing the principle of mutualism [2]. Figure 1 the modalities in the last 10 years:

Private health operators relate to their beneficiaries through contracts, with a predominance of contracts, called health plans, linked to companies through 


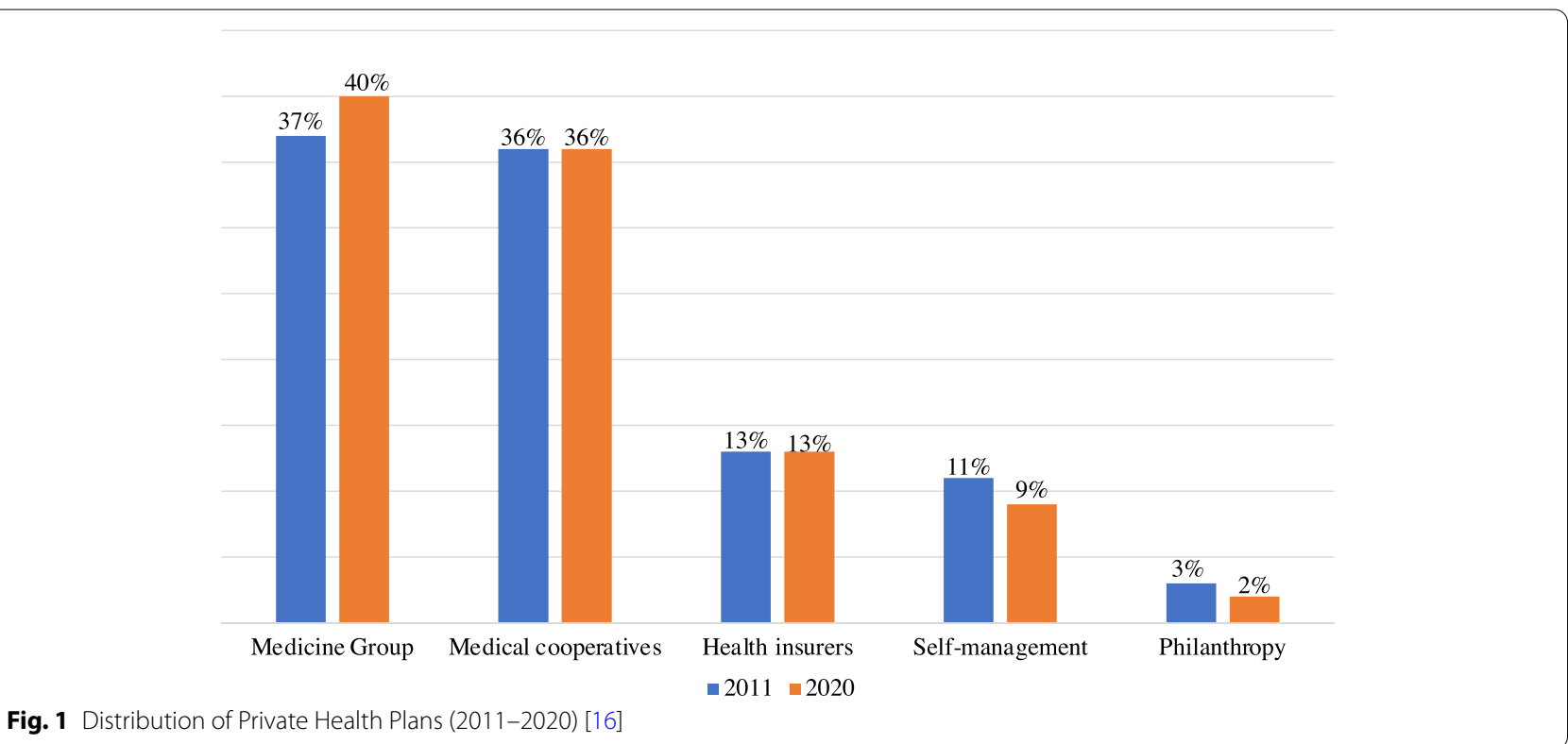

Table 5 Distribution Types of Private Health Plans by Regions in Brazil 2020 [18]

\begin{tabular}{llllllll}
\hline Type of hiring & North & Northeast & Southeast & South & Central West & Unidentified & Total \\
\hline Corporate collective & $1,128,874$ & $4,001,832$ & $20,128,894$ & $4,604,834$ & $2,314,606$ & 28,261 & $32,207,301$ \\
Individual or family & 391,840 & $1,755,343$ & $5,084,947$ & $1,264,072$ & 537,884 & 4299 & $9,038,385$ \\
Collective by adhering & 235,715 & 820,018 & $3,767,746$ & $1,021,740$ & 464,381 & 4701 & $6,314,301$ \\
Uninformed & 3064 & 10,354 & 48,928 & 4663 & 3799 & 1 & 70,809 \\
Unidentified collective & 0 & 77 & 338 & 13 & 0 & 328 \\
Total & $1,759,493$ & $6,587,624$ & $29,030,853$ & $6,895,322$ & $3,320,670$ & 37,262 & $47,631,224$ \\
\hline
\end{tabular}

the so-called "collective business" plans, a fact that is repeated in all regions of the country. Interestingly, this type of contract is related to the level of employability of the country; therefore, it suffers more severe oscillations in a volatile economic system such as the Brazilian system. Table 5 contract modalities and their geographical distribution in the country regions.

Regarding the size of private health institutions, there was a significant reduction in their number, from 1045 institutions in 2011 to 711 in 2020 [16]. This evidence is confirmed by analyzing the data in Table 6 , which shows a growth of $29 \%$ in the number of beneficiaries linked to operators that have more than 500,000 beneficiaries, with a decrease in all other groups, whose intensity of decrease is in smaller institutions, reaching $57 \%$ decrease in institutions with 2001 to 5000 beneficiaries.

Table 7 shows an intense increase in the last 10 years in the general concentration of the private health market, from an RC5 index of 0.22 in 2011 to 0.29 in 2020, reinforcing the hypothesis of an increase in market
Table 6 Grouping of beneficiaries and Horizontal Analysis (2011-2020) [16]

\begin{tabular}{llll}
\hline Grouping & $\mathbf{2 0 1 1}$ & $\mathbf{2 0 2 0}$ & HA \\
\hline Over 500,000 beneficiaries & $17,600,739$ & $22,715,394$ & $29 \%$ \\
100,001 to 500,000 beneficiaries & $12,276,731$ & $11,704,100$ & $-5 \%$ \\
50,001 to 100,000 beneficiaries & $6,410,403$ & $5,669,947$ & $-12 \%$ \\
20,001 to 50,000 beneficiaries & $5,567,096$ & $4,682,160$ & $-16 \%$ \\
10,001 to 20,000 beneficiaries & $2,482,548$ & $1,761,421$ & $-29 \%$ \\
5001 to 10,000 beneficiaries & $1,080,166$ & 757,635 & $-30 \%$ \\
2001 to 5000 beneficiaries & 451,840 & 271,783 & $-40 \%$ \\
1001 to 2000 beneficiaries & 110,730 & 47,105 & $-57 \%$ \\
101 to 1000 beneficiaries & 44,755 & 21,370 & $-52 \%$ \\
1 to 100 beneficiaries & 806 & 309 & $-62 \%$ \\
\hline
\end{tabular}

concentration, which is intense, following the trends of countries such as China [31] and the United States of America [32]. 
Table 7 Historical Series Beneficiaries and RC5 (2011-2020)

\begin{tabular}{lll}
\hline Year & Total Benefit [16] & RC5 \\
\hline 2011 & $46,025,814$ & 0.22 \\
2012 & $47,846,092$ & 0.23 \\
2013 & $49,491,826$ & 0.24 \\
2014 & $50,531,748$ & 0.27 \\
2015 & $49,279,085$ & 0.27 \\
2016 & $47,648,903$ & 0.27 \\
2017 & $47,111,682$ & 0.27 \\
2018 & $47,121,811$ & 0.28 \\
2019 & $47,058,415$ & 0.28 \\
2020 & $47,631,224$ & 0.29 \\
\hline
\end{tabular}

By analyzing the RC5 index of the regions of Brazil, it is possible to understand that the continental dimensions of the country raise extremely different realities, although all demonstrate the increase in market concentration if we compare the years 2011 and 2020. The north and northeast regions of the country show an intense market concentration (0.58), with indicators that exceed the scale of 0.50 , that is, more than half of the beneficiaries are concentrated in the largest five operators of these regions. The southern region has greater market dispersion, in addition to the lower variability in the period (2011-2020). Its RC5 index had a result of 0.26 in 2011 and 0.27 in 2020, as shown in Fig. 2.

Table 8 the 10 largest institutions operating in the Brazilian supplementary health system, as well as the resulting $\mathrm{HHI}$ in 2011 and 2020. The stability of the institution called Bradesco Saúde (0.07) is perceived in the leadership of the $\mathrm{IHH}$, with intense growth in the period of analysis of the publicly traded company called Notre Dame Intermédica Health (0.07). Two institutions deserve special attention when analyzing the indicator of horizontal analysis, Hapvida Medical Care (0.06) with growth of $140 \%$ and São Francisco Health Systems (0.02) with growth of $425 \%$ in the analysis period.

The increase in beneficiaries and market concentration can take two main forms: ordinary growth, or mergers and acquisitions. In the Brazilian private health market, like the United States of America [33] and Costa Rica [34], mergers and acquisitions have

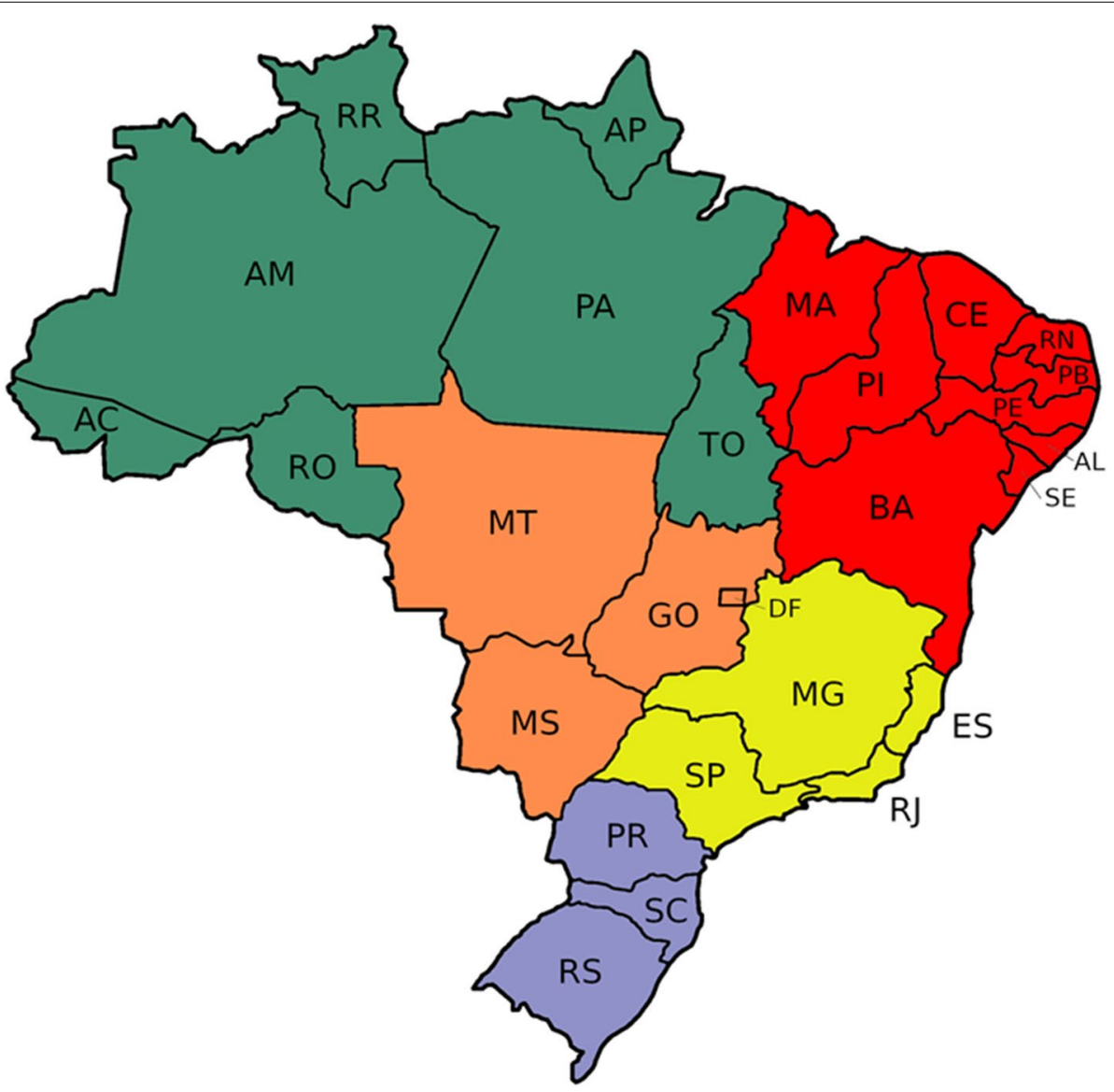

Fig. 2 Private Health Coverage and RC5 by Brazilian Region (2011-2020) 
Table 8 Ten Largest Private Health Institutions by Beneficiaries (2011-2020)

\begin{tabular}{|c|c|c|c|c|c|}
\hline Private Health Institutions & $\begin{array}{l}\text { Beneficiaries Quantity } \\
20,112\end{array}$ & IHH 2011 & $\begin{array}{l}\text { Beneficiaries Quantity } \\
20,202\end{array}$ & IHH 2020 & HA \\
\hline Bradesco Health S.A. & $2,988,834$ & 0.07 & $3,277,018$ & 0.07 & $10 \%$ \\
\hline Notre Dame Intermédica Health S.A. & $2,140,143$ & 0.05 & $3,241,622$ & 0.07 & $51 \%$ \\
\hline Amil International Medical & $2,624,621$ & 0.06 & $2,893,453$ & 0.06 & $10 \%$ \\
\hline Hapvida Medical Care & $1,134,584$ & 0.03 & $2,721,072$ & 0.06 & $140 \%$ \\
\hline South America Cia Health Insurance & $1,279,444$ & 0.03 & $1,858,761$ & 0.04 & $45 \%$ \\
\hline Unimed National Central & $1,168,769$ & 0.03 & $1,808,907$ & 0.04 & $55 \%$ \\
\hline Unimed - Belo Horizonte & 971,061 & 0.02 & $1,297,348$ & 0.03 & $34 \%$ \\
\hline San Francisco Systems and Health & 146,728 & 0.00 & 770,029 & 0.02 & $425 \%$ \\
\hline Unimed-Rio Cooperativa Médica & 774,619 & 0.02 & 736,615 & 0.02 & $-5 \%$ \\
\hline Caixa de Assist. dos Funcionários & 693,620 & 0.02 & 634,214 & 0.01 & $-9 \%$ \\
\hline
\end{tabular}

Table 9 Assets acquired by Private Health Institutions (20182020)

\begin{tabular}{ll}
\hline Assets Acquired by Supplementary Health Operators & $\begin{array}{l}\text { Number of } \\
\text { Operations }\end{array}$ \\
\hline Private Health Institutions & 27 \\
Hospitals & 18 \\
Benefits Administrator & 3 \\
Miscellaneous (Clinics, Brokers, Laboratories and Technol- & 4 \\
ogy Companies) & \\
\hline
\end{tabular}

Table 10 Private Health Institutions sold (2018-2020)

\begin{tabular}{ll}
\hline Typology of Buyer Entities & $\begin{array}{l}\text { Number of } \\
\text { Operations }\end{array}$ \\
\hline Private Health Institutions & 27 \\
Hospitals & 6 \\
Diagnosis & 2 \\
Miscellaneous (Clinics, Brokers, Laboratories and Technol- & 3 \\
ogy Companies) & \\
\hline
\end{tabular}

increasingly presented itself as alternatives. In the healthcare market, health insurance operators have been especially active in buying and selling assets. Of the 196 transactions of mergers and acquisitions of the Brazilian health market carried out between 2018 and 2020, 91 private health institutions are buyers of assets (53) or sellers (38).

Table 9 the predominance of acquisitions by private health institutions, focused on other private health plan (27) or hospitals (18), thus promoting market concentration and service delivery through their hospitals.

According to Table 10 private health institutions were predominantly sold to other private health institutions (27), with few events of selling operators to hospitals (6).
According to Fig. 3 among the five main health entity asset buyers in the periods 2018 to 2020 , two are private health institutions. Hapvida Health Care and Notre Dame Intermédica with 19 and 22 operations respectively, stand out as they both are publicly traded in the Brazilian market.

By observing the totality of mergers and acquisitions in the health sector in Brazil, from 2018 to 2020, as shown Fig. 4 centrality of operators that appear as buyers of assets in the market (black), which represent a relevant growth of their operations through mergers and acquisitions, a variable that helps in the analysis of the quantitative decrease of active operators in the market. However, the operators sold in the period present themselves in green, with a relational link with their buyer, represented by the black arrow.

As shown in Table 11 some operators are especially prominent in mergers and acquisitions in the period demonstrated. Among them, there is the institution Notredame Intermédica, being the third institution with the highest degree of total centrality in the private health market (22.0), followed by Hapvida in fourth place (19.0), and Qualicorp in seventh place (7.0), all publicly trading on the Brazilian stock exchange.

Table 12 shows the main characteristics of the 10 main private health institutions in Brazil, which together concentrate more than 19 million beneficiaries [16].

The obvious concentration of the market in fewer operators and the absence of change in the overall number of beneficiaries creates "giants" in the market. Among them, the market leader in 2020, with an HHI of 0.07 and growth of $10 \%$ in the period 2011 to 2020 is Bradesco Health, whose growth strategy is strongly focused on common shares, making little use of growth via mergers and acquisitions in the years 2018 to 2020, with a centrality degree of only 1.0. 


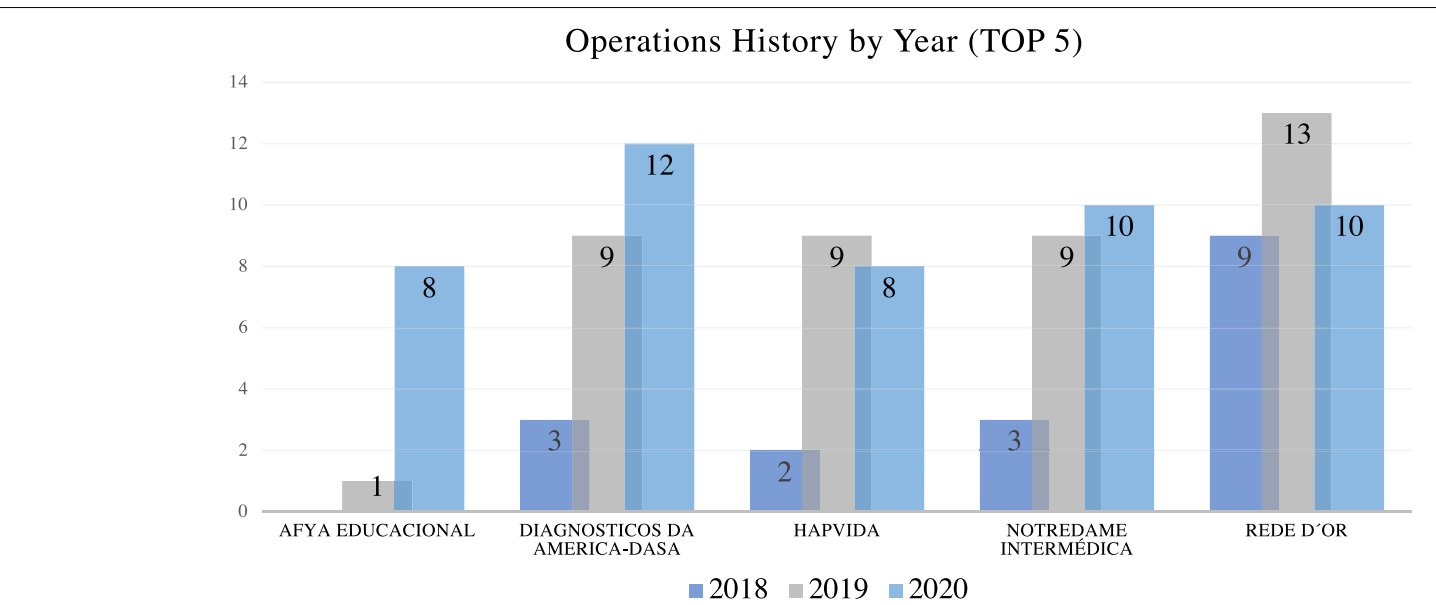

Fig. 3 Main buyer entities (2018-2020)

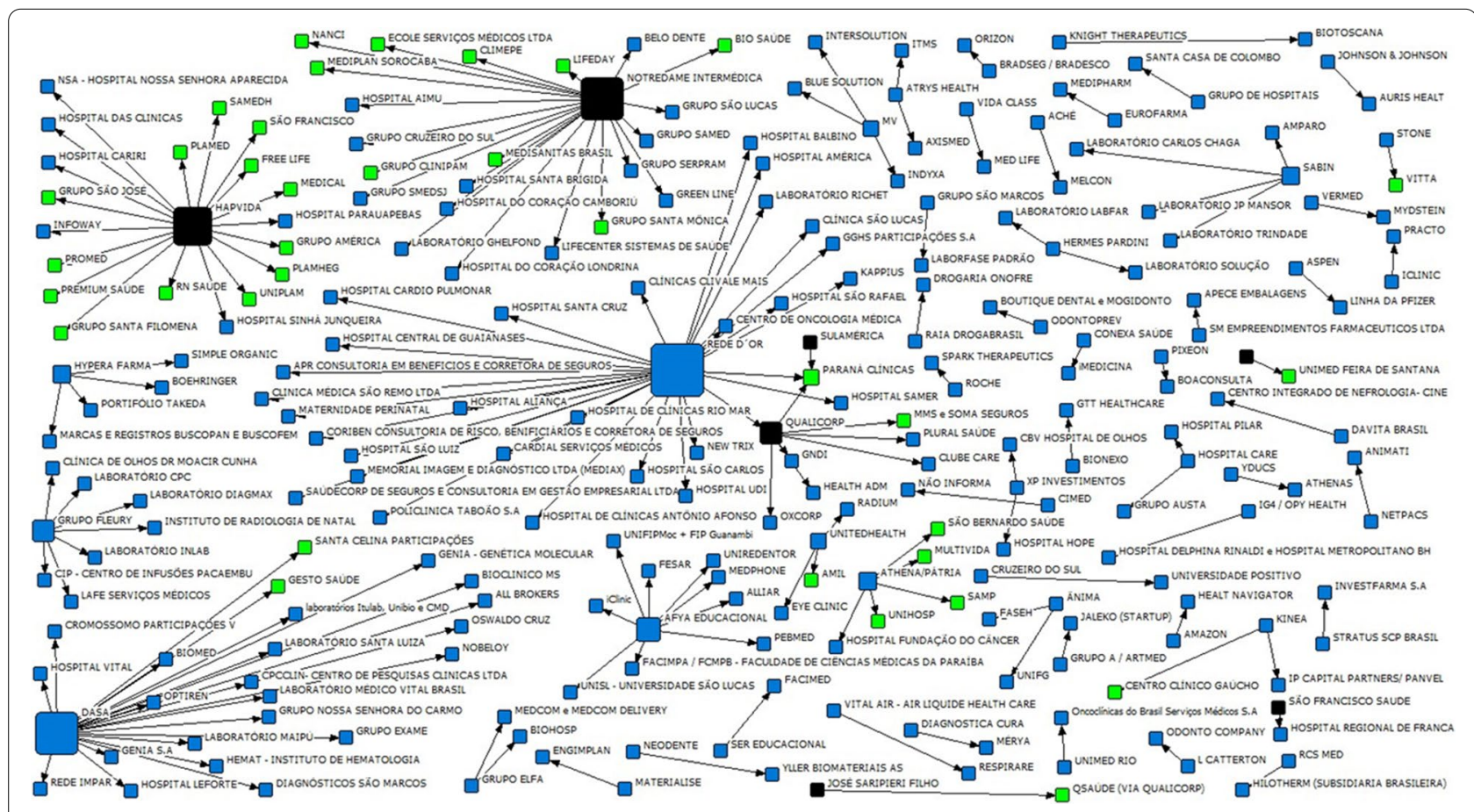

Fig. 4 Sociogram of mergers and acquisitions in the health sector (2018-2020)

Although Bradesco Health leadership is solid throughout the period 2011-2020, the massive mergers and acquisitions operations of the operators Notre Dame Intermédica and Hapvida Health Care, both publicly trading on the Brazilian stock exchange, have been demonstrating relevant results and contributing intensely to the market concentration. Its HHI of 0.07 and 0.06 and centrality level of 22.0 and 19.0 respectively, demonstrate their appetites for growth support through mergers and acquisitions that focused on other private health institutions and hospitals.

By more careful analyses, some of the data from the 10 mains private health institutions in the country can be evidenced as different strategies of growth and market positioning in their corporate structures, volume of beneficiaries, average billing ticket, spending structure, 
Table 11 Main buyer entities (2018-2020)

\begin{tabular}{llll}
\hline n. & Name of The Institution & $\begin{array}{c}\text { Degree of } \\
\text { Centrality }\end{array}$ & Operation Category \\
\hline 1 & Rede D'Or & 30.0 & Hospital \\
2 & Dasa & 23.0 & Diagnosis \\
3 & Notredame Intermédica & 22.0 & Private Health Institutions \\
4 & Hapvida & 19.0 & Private Health Institutions \\
5 & Afya Educational & 9.0 & Medical Education \\
6 & Fleury Group & 7.0 & Diagnosis \\
7 & Qualicorp & 7.0 & Private Health Institutions \\
8 & Athena/Homeland & 5.0 & Hospital \\
9 & Hypera Pharma & 4.0 & Pharmaceutical \\
10 & Sabin & 4.0 & Diagnosis \\
\hline
\end{tabular}

value of their assets, HHI, degree of centrality, loss, and supplementary health performance index. Although the numbers are impressive, market interaction strategies are different, which will lead us to futile different performances in future individual analyses, with an apparent and inevitable growth of mergers and acquisitions operations.

Finally, it is worth highlighting the particularity within Brazilian private health of the cooperative system called Unimeds, founded in 1975, as one of the largest health cooperatives in the world [46]. It has 270 private health institutions with a total of $17,707,733$ beneficiaries. Together they have an HHI of 0.37, representing the highest concentration of the Brazilian market with a growth of only $3 \%$ of the number of beneficiaries in the period from 2011 to 2020.

\section{Discussion and conclusion}

Health care is a complex economic and social system [47], which combines market elements of public and social interest in a single environment. This intriguing combination in Brazil, like the Chinese $[8,31]$ and United States of America [32] systems, is presented through the public and private system, with the great challenge of providing access and health care for all Brazilian citizens.

The representativeness of health in the face of human existence and care and the economy are notorious, as perceived in the Canadian territory [7]. However, in Brazil, the challenges in the search for alternatives that promote a problem-effective discussion are emerging and endowed with many vulnerabilities. As the representativeness of the sector, before the economy, is on the scale of $9 \%$ of the GDP, employing more than 4 million people, the investment in intelligence from the previous history is urgent, either by access and quality of health care or by economic importance.

In this sense, describing and analyzing the complementarity of Private Health before the Unified Health System in history can help guide health scenarios and trends in Brazil. Based on this contribution, this research objectively and clearly demonstrates the main historical assumptions of Brazilian private health, enabling the essential perception of complementarity between the public and private health care systems.

This provocation currently directly interferes with $24.5 \%$ of the country's health demand, which makes about $\$ 30$ billion a year. Of this, approximately $74 \%$ is reinvested in spending on their health care through a decreasing number of institutions (711), with historical stability of total beneficiaries, increasingly converted to business plans (70\%), this being the only modality in full growth in the last 10 years of the market. Importantly, the dependence of this type of contract, the performance of employability of the country, and the maintenance of contracts depend directly on the capacity of the country to generate employment and income.

Table 12 General data of the 10 largest private health institutions in Brazil (2020)

\begin{tabular}{|c|c|c|c|c|c|c|}
\hline Operator & Users & $\mathrm{IHH}$ & AH (2011-2020) & $\begin{array}{l}\text { Mergers and } \\
\text { Acquisitions } \\
(18-20)\end{array}$ & Accident Rate & IDSS (2019) [35] \\
\hline Bradesco Health S.A. (1984) [36] & $3,277,018$ & 0.07 & $10 \%$ & 1.0 & $76.45 \%$ & 0.70 \\
\hline Notre Dame Intermédica S.A. (1968) [37] & $3,241,622$ & 0.07 & $51 \%$ & 22.0 & $71.40 \%$ & 0.94 \\
\hline Amil Assist. International Medical. (1978) [38] & $2,893,453$ & 0.06 & $10 \%$ & 0 & $77.06 \%$ & 0.91 \\
\hline Hapvida Medical Care. (1991) [39] & $2,721,072$ & 0.06 & $140 \%$ & 19.0 & $66.50 \%$ & 0.75 \\
\hline South America Health Insurance Company. (1895) [40] & $1,858,761$ & 0.04 & $45 \%$ & 1.0 & $76.90 \%$ & 0.76 \\
\hline Unimed National Central. (1998) [41] & $1,808,907$ & 0.04 & $55 \%$ & 1.0 & $82.80 \%$ & 0.93 \\
\hline Unimed - Belo Horizonte. (1971) [42] & $1,297,348$ & 0.03 & $34 \%$ & 0 & $68.89 \%$ & 0.94 \\
\hline San Francisco Health Systems. (2019) [43] & 770,029 & 0.02 & $425 \%$ & 1.0 & - & 0.86 \\
\hline Unimed-Rio Medical Cooperative. (1972) [44] & 736,615 & 0.02 & $-5 \%$ & 1.0 & $72.00 \%$ & - \\
\hline Caixa de Assist. dos Funcionários (1944) [45] & 634,214 & 0.01 & $-9 \%$ & 0 & $77.50 \%$ & - \\
\hline
\end{tabular}


Notoriously, the growth of large private health institutions, with a concentration of more than 500,000 beneficiaries, show an increase of $29 \%$ in the years 2011 to 2020 , to the detriment of institutions with a lower concentration of beneficiaries, which present as percentage degrowth in any scale in this period. The market concentration in large institutions can also be evidenced by the exponential increase of the RC5 indicator from 2011 (0.22) to 2020 (0.29).

This reality is more pronounced in the regions of the country with the lowest rate of private health coverage, reaching 0.58 in 2020 in the north (9\% private health coverage) and northeast ( $11 \%$ private health coverage) and is less accentuated in the southern region $(0.27)$, whose private health coverage is $23 \%$.

Therefore, it is possible to perceive an intense trend of concentration of Brazilian private health in large institutions that capitalized on and have a great appetite for growth through mergers and acquisitions, whether from smaller private health institutions that integrate their health care networks, following complementary health models already consolidated in countries such as China [8, 31], and the United States of America [32], among others.

This concentration projects a market with fewer options and competitiveness that can lead to a concentration of risks, raising potential frequencies of isolated failures according to user experience. However, according to health operators, they lead to a decrease in transaction costs and increase the operational effectiveness of care [11]. These hypotheses are still fragile in the literature applied to the private health sector and, therefore, they figure only as one of the most varied scenarios to be considered. Another important factor to be considered is the analysis of this scenario in countries of continental dimensions such as Brazil, which may present specific particularities concerning health, whether public or private, in its different regions, this favors exponentially the trend of market concentration growth, by an even greater flow of M\&A operations, favored by the growing number of entities in the sector, listed on the stock exchange.

Finally, similar to the United States of America model [32], the complementarity of Brazil's understanding of private health is worth highlighting, as it contributes to the access and qualification of health care, safeguarding premises of cost-effectiveness, quality, humanization and access to health, emphasizing the role of regulatory agencies in the sector, in the improvement of governance tools that guarantee the rights and duties of all stakeholders [48] from an integrated view of health, avoiding its eminently mercantility [33].

\section{Supplementary Information}

The online version contains supplementary material available at https://doi. org/10.1186/s12913-021-07376-2.

Additional file 1.

Acknowledgements

Not applicable.

Authors' contributions

June Alisson Westarb Cruz: He structured the text of the article and organized the relationship between the data and the theoretical approach, analyzed the practical impacts and suggestions of the research and submitted the article to the jornal; Arivelton Loeschke Gomide and Gisele de Paula Linhares: Organized the database, tables, graphs and the structure of the article; Maria Alexandra Viegas Cortez da Cunha and Sandro Marques: Revised the theoretical approach of the article; Thyago Proença de Moraes and Felipe Francisco Tuon: It reviewed the coherence of the research, formatting and revision of the English language and the theoretical approaches to network analysis. The author(s) read and approved the final manuscript.

Funding

Not applicable.

Availability of data and materials

The data sets generated and / or course during the current study are available in the files sent to the journal.

\section{Declarations}

Ethics approval and consent to participate

Not applicable.

Consent for publication

Not applicable.

Competing interests

None of the authors has conflicting interests with the research.

\section{Author details}

${ }^{1}$ Fundação Getúlio Vargas - EAESP, São Paulo, Brazil. ${ }^{2}$ Pontifical Catholic University of Paraná, Curitiba, Brazil. ${ }^{3}$ School of Business, Pontifical Catholic University of Paraná, Curitiba, Paraná 80215-901, Brazil. ${ }^{4}$ Department of Otolaryngology, Head and Neck Surgery, School of Medicine, Stanford University, Palo Alto, USA. ${ }^{5}$ Pontifical Business School at the Catholic University of Paraná - EUA, Curitiba, Brazil.

Received: 17 July 2021 Accepted: 18 November 2021

Published online: 10 January 2022

References

1. IBGE. 2021. Available in: https://www.ibge.gov.br

2. Batista AM, Cruz JAW, Piccoli PGR. Insolvency model applied to medical cooperative organizations: brazilian market analysis. Manage Magazine Coop Org. 2020;7(13). https://doi.org/10.5902/2359043240561.

3. Castro MC, Massuda A, Almeida G, Menezes-Filho NA, Andrade MV, Noronha KVMS, et al. Brazil's unified health system: the first 30 years and prospects for the future. Lancet. 2019;394. https://doi.org/10.1016/S01406736(19)31243-7.

4. Rocha R, Atun R, Massuda A, Rache B, Spinola P, Nunes L, et al. Effect of socioeconomic inequalities and vulnerabilities on health-system preparedness and response to COVID-19 in Brazil: a comprehensive analysis. Lancet Glob Health. 2021. https://doi.org/10.1016/S2214-109X(21) 00081-4. 
5. Chaves VM, Zdziarski AD, Cruz JAW, Vieira da Silva W, da Silva CL. Efficiency analysis of the unified health system service in parana municipalities. J Global Competitiveness Governabil. 2017;11(2). https://doi.org/10.3232/ GCG.2017.V11.N2.02.

6. The World Bank. 2021. Available in: https://data.worldbank.org/indicator/ SI.POV.GINI?locations=ZM

7. Marchildon G, Allin S. Health Systems in Transition. 3rd ed. Canada: University of Toronto Press; 2021. https://doi.org/10.3138/9781487537517.

8. Zhu K, Zhang L, Yuan S, et al. Health financing and integration of basic medical insurance systems for urban and rural residents in China. Int J Equity Health. 2017;16:194. https://doi.org/10.1186/s12939-017-0690-z.

9. The Lancet. Covid-19 in Brazil: so what? 2020. https://doi.org/10.1016/ S0140-6736(20)31095-3.

10. Loesch G, Cruz J, Gasparetto J, Oliveira D, Telles J, Tuon F. Cost minimization analysis of outpatient parenteral/oral antibiotic therapy in a trauma hospital: Public health system. Infect Control Hosp Epidemiol. 2021:1-6. https://doi.org/10.1017/ice.2021.22.

11. Gasparetto J, Tuon FF, dos Santos Oliveira D, et al. Intravenous to oral antibiotic replacement: a cross-sectional study in intensive care units. BMC Infect Dis. 2019;19:650. https://doi.org/10.1186/s12879-019-4280-0.

12. Paim J, Locks C, Almeida C, Bahia L, Macinko J. The Brazilian health system: history, advances and challenges. Lancet. 2011; Available in: http://bvsms. saude.gov.br/bvs/artigos/artigo_saude_brasil_1.pdf.

13. Doniec K, Dall' Álba R, Lawrence K. Austerity Threatens Universal Health Coverage in Brazil. Lancet. 2016;388(10047):867-8. https://doi.org/10. 1016/S0140-6736(16)31428-3.

14. Institute for Supplementary Health Studies. Employment Report in the Health Production Chain. 2021. Available in: https://www.iess.org.br/cms/ rep/RECS_Jan21.pdf

15. Anahp. Sector Analysis. 2021. Available in: https://www.anahp.com.br/ dados-do-setor/

16. National Health Agency. 2021. Available in: http://www.ans.gov.br/ansta bnet/index.htm

17. Brazilian Federation of Hospitals. Scenarios of hospitals in Brazil. 2020. Available from: https://www.fbh.com.br/wp-content/uploads/2021/04/ Cenarios_2020.pdf

18. Brazil. Ministry of Health. SUS date. Tabnet health Information. 2021. Available: http://www2.datasus.gov.br/DATASUS/index.php?area $=02$

19. Singer P, Campos O. Prevent and heal: social control through health services. Rio de Janeiro: Forensic-University; 1978

20. Braga JC, Paula SG. Health and social security: social policy studies. São Paulo: Cebes/Hucitec; 1981

21. Fonseca CMO. Health in the Vargas government (1930-1945): institutional duality of a public good. Rio de Janeiro: Fiocruz; 2007.

22. Vieira, MMF, Vilarinho, PF. The Field of Supplementary Health in Brazil. Administration Sciences Magazine, v.6 (11). 2005. Available in: http:// www.ans.gov.br/images/stories/Materiais_para_pesquisa/Materiais_por_ assunto/Artigo_O_Campo_da_saude_suplementar_no_Brasil.pdf

23. Escorel S. Health turnaround: origin and articulation of the health movement. Rio de Janeiro: Fiocruz; 1998.

24. Paim JS. Brazilian sanitary reform: contribution to understanding and criticism. Savior, Rio de Janeiro: Edufba; Fiocruz; 2008.

25. Moreira Filho MM. The Opening of Capital in Health Enterprises. GV Saúde Debates. (4); 2007

26. Brazil. Law 9.656/98 - Health Plan Operators. Available in http://www. planalto.gov.br/ccivil_03/leis/19656.htm

27. Brazil. Law 9.961/2000 - CAMSS. Available from: http://www.planalto.gov. br/ccivil_03/leis/19961.htm

28. Trading Economics. Data Base Brazil. 2021. Available in: https://pt.trad ngeconomics.com/brazil/indicators

29. VanHoose D. Bank and market structure and monetary control. J Money, Credit, Bank. 1985;17(3):298-311. https://doi.org/10.2307/1992626.

30. Borgatti SP, Everett MG, Freeman LC. Ucinet for windows: software for social network analysis. Harvard: Analytic Technologies; 2002

31. Dong K. Medical insurance system evolution in China. China Econ Rev. 2009:20(4). https://doi.org/10.1016/..chieco.2009.05.011.

32. Georges CB. From MMXX to MMXXI: the way forward to renew American healthpolicy. Am J Public Health. 2021;111:8-9. https://doi.org/10.2105/ AJPH.2020.306054.
33. Krachler N, Greer I, Umney C. Can public healthcare afford marketization? Market principles, mechanisms, and effects in five health systems. Public Adm Rev. 2021. https://doi.org/10.1111/puar.13388.

34. Law, E.Y.; Vargas-Winiker, F. M\&A Report: Costa Rica. International Financial Law Review, London, 2021. Available in: https://www.proquest.com/ docview/2514199276?pq-origsite=gscholar\&fromopenview $=$ true

35. IDSS. 2020. Available in: http://www.ans.gov.br/images/stories/Materiais_ para_pesquisa/Perfil_setor/idss/anexo_do_relatorio-listagem_completa_ dos_resultados_do_idss-2019-v01-2021_03_04.pdf

36. Bradesco. 2021. Available in: https://www.bradescoseguros.com.br/clien tes/institucional

37. GNDI. 2021. Available in: https://www.gndi.com.br/grupo/sobre-o-grupo

38. Amil. 2021. Available in: http://www.amil.com.br/institucional/\#/demon strativos-financeiros

39. Hapvida. 2021. Available in: https://www.hapvida.com.br/site/sites/defau It/files/file_management/pdfs/816919 _ _df ham_31.12.2020 final _ 31 . 03.21_cliente_1.pdf

40. Sulamérica. 2021. Available in: https://relatorioanual2020.sulamerica.com $\mathrm{br} / \mathrm{hml} / \mathrm{index} \cdot \mathrm{html}$

41. Unimed National. 2021. Available from: https://www.centralnacional unimed.com.br/documents/2520476/0/Demonstrativo+Finaceiro_2020. pdf/9e6dadf5-01f3-49b3-8f28-158e728e10ab

42. Unimed Belo Horizonte. 2021. Available in: https://portal.unimedbh.com. $\mathrm{br} /$

43. São Francisco Saúde. 2021. Available in: https://www.saofrancisco.com. br/imprensa/noticias/demonstracao-financeira

44. Unimed Rio. 2021. Available in: http://www.unimedrio.com.br/

45. Cassi. 2021. Available in: https://www.cassi.com.br/relatorio2020/

46. Unimed. 2021. Available in: https://www.unimed.coop.br/home/sistemaunimed/a-unimed

47. Cruz V, Coutinho M. Private Health Plans: a look at the interaction between State and Market. In: Plural knowledge: academic production in society, culture and social work / Rosemere Maia and Verônica Cruz (org.). Rio de Janeiro: UFRJ Publishing House: Graduate Program in Social Work; 2020. Available from: http://www.editora.ufrj.br/Dynamicltems/livrosaber tos-1/CCNC-digital-v6.pdf\#page $=151$

48. Rattani A, Hyder A. Operationalizing the ethical review of Global Health policy and systems research: a proposed checklist. J Law Med Ethics. 2021;49(1):92-122. https://doi.org/10.1017/jme.2021.15.

\section{Publisher's Note}

Springer Nature remains neutral with regard to jurisdictional claims in published maps and institutional affiliations.

Ready to submit your research? Choose BMC and benefit from

- fast, convenient online submission

- thorough peer review by experienced researchers in your field

- rapid publication on acceptance

- support for research data, including large and complex data types

- gold Open Access which fosters wider collaboration and increased citations

- maximum visibility for your research: over 100M website views per year

At BMC, research is always in progress.

Learn more biomedcentral.com/submissions 